OPEN ACCESS

\title{
The IGD-TP Geodisposal 2014: Introduction to the Conference Proceedings
}

\section{4-26 June 2014, The University of Manchester, Manchester, UK}

\author{
Katherine Morris*, Nick D. Bryan, Nicholas D. M. Evans and Ray Kowe
}

THE 'Implementing Geological Disposal Technology Platform' (IGD-TP) is composed of European waste-management organizations and has a vision that "by 2025 the first geological disposal facilities for spent fuel, high-level waste and other long-lived radioactive waste will be operating safely in Europe".

The first IGD-TP Geodisposal Conference was held at The University of Manchester, UK from June $24^{\text {th }}-26^{\text {th }} 2014$ and provided a new forum for researchers in this area to present their work. The Conference brought together $>270$ delegates from across 23 countries and an important aspect of the conference was to showcase and publish research relevant to geological disposal of radioactive waste. The conference was also an opportunity for more advanced geological programmes to share $>30$ years of Research and Development and Demonstration (RD \& D) and implementation experience in geological disposal with less advanced programmes.

The event received funding from the European Union's European Atomic Energy Community's (EURATOM) Seventh Framework programme FP7 (2007-2013) under grant agreements in $\mathrm{n}^{\circ} 249396$, Sec IGD and $n^{\circ} 323260$, Sec IGD2. Additional support for the conference proceedings was received from: Radioactive Waste Management Limited; The University of Manchester Dalton Nuclear Institute Research Centre for Radwaste

* E-mail: katherine.morris@manchester.ac.uk DOI: $10.1180 / \mathrm{minmag} .2015 .079 .6 .00$
Disposal; The Royal Society of Chemistry; The Geological Society, UK; The Mineralogical Society, UK; the National Nuclear Laboratory; the STFC EnvRadNet Network; and the NERC BIGRAD Consortium.

The Conference organising committee comprised: Raymond Kowe, Radioactive Waste Management Ltd., UK; Nic Bilham, Geological Society, UK; Nick Bryan, National Nuclear Laboratory, UK; Gunnar Buckau, Joint Research Centre, Germany; Jacques Delay, ANDRA, France; Daniela Diaconu, Institute for Nuclear Research, Romania; Nick Evans, Loughborough University, UK; Hans Forsström, SKB, Sweden; Erik Kremer, NWMO, Canada; Katherine Morris, The University of Manchester, UK; Kevin Murphy, The Mineralogical Society, UK; Cherry Tweed, Radioactive Waste Management Limited, UK; Ewoud Verhoef, COVRA, The Netherlands; Juhani Vira, POSIVA, Finland; and Claudia Vivalda, Nidia srl, Italy. The scientific committee consisted of: Katherine Morris, The University of Manchester, UK; Nick Bryan, National Nuclear Laboratory, UK; Nick Evans, Loughborough University, UK; Horst Geckeis, Karlsruhe Institute of Technology, Germany; José Luis Fuentes-Cantillana, AITEMIN, Spain; Mats Jonsson, KTH Royal Institute of Technology, Sweden; Wolfgang Kickmaier, MCM International, Switzerland; Rebecca Lunn, University of Strathcylde, UK; André Maes, KU Leuven, Belgium; Caroline Peacock, University of Leeds, UK; Karsten Pedersen, Chalmers University of Technology, Sweden; Richard Shaw, British Geological Survey, UK; and Behnam Taebi, TU

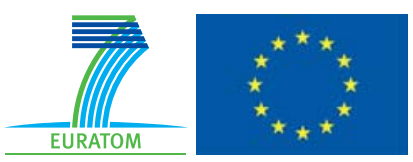

The publication of this research has been funded by the European Union's European Atomic Energy Community's (Euratom) Seventh Framework programme FP7 (2007-2013) under grant agreements $n^{\circ} 249396$, SecIGD, and n`323260, SecIGD2. 
Delft, Netherlands. Both the organizing committee and the scientific committee would like to thank the sponsors of the Conference. Papers derived from the conference talks and posters are presented in this special issue of Mineralogical Magazine. All of the papers underwent independent peer review and the Mineralogical Magazine IGD-TP Geodisposal 2014 special issue Guest Editors Katherine Morris, The University of Manchester; Nick Bryan, National Nuclear Laboratory and Nick Evans, Loughborough University would like to express their thanks to all the reviewers that provided detailed comments and feedback on all the papers which were submitted to the special issue.

The conference sessions were organized into thematic sessions which were based around the IGD-TP's Strategic Research Agenda and other research related to geological disposal across Europe. The key topics covered were: radionuclide and gas behaviour; natural systems including biogeochemistry, biosphere and geosphere; monitoring; engineered barriers, wasteforms and criticality; societal aspects; national programmes for geological disposal; safety case; and, disposal concept and technology development. There was also a discussion session on future IGD-TP activities and Horizon 2020-funded projects involving newer member states.

\section{Section 1: Radionuclide and Gas Behaviour}

The first section includes papers on: gas-transport results from the EU FORGE project (Bond et al., 2015); behaviour of uranium with the iron oxide magnetite (Marshall et al., 2015); carbon-14 behaviour in alkaline iron-water systems (Wieland and Hummel, 2015); the fate of the radionuclide neptunium-237 in alkaline sediment microcosms (Williamson et al., 2015); retention of chlorine-36 in alkaline cement systems (van Es et al., 2015); bentonite colloid behaviour in ternary systems (Sherriff et al., 2015); gas migration in a highlevel waste disposal tunnel (Justinavicius and Poskas, 2015); carbon-14 behaviour in reactor graphite cores (Payne et al., 2015); and a paper on visualization of flow paths in clay minerals (Wiseall et al., 2015).

\section{Section 2: Natural Systems Including Biogeochemistry, Biosphere and Geosphere}

The discussion of natural systems includes a diverse range of papers covering: iodine behaviour in model sediment systems (Guido-Garcia et al.,
2015); characterization of the mineralogy and redox reactivity of potential GDF host rocks in the UK (Quirke et al., 2015); modelling studies applying pore network models to Opalinus clay (Xiong and Jivkov et al., 2015); the behaviour of pertechnetate in hyperalkaline conditions in the context of recrystallization of kaolinite (Littlewood et al., 2015); the impact of GDFrelevant temperatures on clay systems in the context of high-level waste disposal (Jobmann and Meleshyn, 2015); the impact of humic substances on metal ion behaviour (Bryan et al., 2015); an evaluation of the Herberts Quarry site in the UK as an analogue for intermediate level waste disposal (Moyce et al., 2015); a study examining the inhibition of colloidal formation in intermediate level waste systems (Felipe-Sotelo et al., 2015); microbial degradation of cellulosic materials under conditions relevant to intermediate level waste disposal (Bassil et al., 2015); microbial degradation of isosaccharinic acid under far-field conditions (Kuippers et al. 2015); radiation damage studies in natural sheet silicate minerals (Bower et al., 2015); and a representation of biosphere systems in the UK relevant to higher activity waste disposal (Walke et al., 2015).

\section{Section 3: Monitoring}

Here, a paper on applying a micro-electro-mechanical system to monitor conditions in a bentonite buffer system is discussed (Yang et al., 2015).

\section{Section 4: Engineered barriers, wasteforms and criticality}

Here, papers cover: bentonite buffer erosion in fracture systems (Reid et al., 2015); carbon-14 behaviour in the engineered geological disposal facility system (Doulgeris et al., 2015); modelling post-closure criticality events associated with spent-fuel disposal (Mason et al., 2015); the European Network of Testing Facilities for the 'Quality Checking of Radioactive Waste Packages' (ENTRAP) programme and its potential interaction with the IGD-TP (Tietze-Jaensch et al., 2015); manufacturing of copper canisters for geological disposal (Hernandez-Selva et al., 2015); dissolution of MAGNOX blend nuclear waste glass (Cassingham et al., 2015); the impact of thermal cycling on bentonite permeability (Zihms and Harrington, 2015); and on the likelihood and consequences of post-closure criticality in a geological disposal facility (Winsley et al., 2015). 


\section{Section 5: Societal Aspects}

This session includes contributions on: integrating societal concerns into R\&D for geological disposal at a national level (Martell and van Berendoncks, 2015); and a paper on the investigation of attitudes, needs and expectations of a local community where waste disposal is relevant (Constantin et al., 2015).

\section{Section 6: National programmes for geological disposal}

In this section, the conference papers cover: the Lithuanian programme for spent fuel (Poskas et al., 2015); the Implementing Geological Disposal Technology Platform in the context of addressing the needs of new member states (Kowe et al., 2015); and an overview of the less advanced programmes and their requirements (Diaconu et al., 2015).

\section{Section 7: Safety Case}

Here papers are presented on: the safety case for the biosphere in the context of the mature, Finnish safety case (Ikonen, 2015); the influence of anthropogenic $\mathrm{CO}_{2}$ on post-closure performance assessment (Lord et al., 2015); the design of waste packaging for heat generating wastes (Myers et al., 2015); development of a generic safety case narrative for the UK geological disposal facility (Bailey, 2015); and an integrated approach to disposal of the UK's carbon-14 wastes (Lever and Vines, 2015).

\section{Section 8: Disposal concept and technology development}

In this final section, the papers cover: technology transfer from the space and physics sectors (Direto et al., 2015); and, the state-of-the-art with respect to repository concepts for crystalline rocks (Kronberg et al., 2015).

\section{Acknowledgements}

The editors acknowledge the following people for their essential help and support in delivery of both the conference and the conference proceedings:

Christophe Davies, European Commission DG RTG. Monica Hammarström, Chair IGD-TP; Jacques Delay, Secretary General IGD-TP; IGD-TP Executive Group members.

Cherry Tweed, Chief Scientific Advisor; Jon Martin, Head of Research, RWM.

Kevin Murphy and Helen Kerbey, the Mineralogical Society of Great Britain and Ireland, for all their assistance with this special issue of Mineralogical Magazine.

Oliver Street and Janet Adnams, for administrative and conference management; and the members of the Research Centre for Radwaste Disposal at The University of Manchester.

\section{References}

Bailey, L.E.F. (2015a) Development of a Generic Safety Narrative for the UK Geological Disposal Facility. Mineralogical Magazine, 79, 1633-1640.

Bassil, N.M., Bewsher, A.D., Thompson, O.R. and Lloyd, J.R. (2015) Microbial degradation of cellulosic material under intermediate-level waste simulated conditions. Mineralogical Magazine, 79, 1433-1441.

Bond, A.E., Thatcher, K.E., and Norris S. (2015) Multiscale gas transport modelling for the EC FORGE Project. Mineralogical Magazine, 79, 1245-1249.

Bower, W.R., Pearce, C.I., Droop, G.T.R., Mosselmans, J. F.W., Geraki, K. and Pattrick, R.A.D. (2015) Radiation damage from long term alpha particle bombardment of silicates - a microfocus XRD and Fe $K$-edge XANES study. Mineralogical Magazine, 79, 1455-1466.

Bryan, N., Jones, D., Keepax, R., Farrelly, D., Abrahamsen, L., Beard, R., Li, N. and Weir, G. (2015) Factors affecting the dissociation of metal ions from humic substances. Mineralogical Magazine, 79, 1397-1405.

Cassingham, N., Corkhill, C.L., Backhouse, D.J., Hand, R.J., Ryan, J.V., Vienna, J.D. and Hyatt, N.C. (2015) The initial dissolution rates of simulated UK Magnox ThORP blend nuclear waste glass as a function of $\mathrm{pH}$, temperature and waste loading. Mineralogical Magazine, 79, 1529-1542.

Constantin, A., Constantin, M. and Diaconu, D. (2015) Investigation of the attitudes, needs, and expectations of the Saligny community. Mineralogical Magazine, 79, 1573-1580.

Diaconu, D., Ivanov, I., Železnik, N., Kralj, M. and Zakrzewska, G. (2015) Overview of less advanced programmes and their requirements. Mineralogical Magazine, 79, 1599-1606.

Direito, S.O.L., Clark, S., Cousins, C., Fujita, Y., Gluyas, J., Harley, S., Holmes, R.J., Hutchinson, I.B., Kudryavtsev, V.A., Lloyd, J., Main, I.G., Naylor, M., Payler, S., Smith, N., Spooner, N.J.C., Telfer, S., Thompson, L.F., Wouters, K., Wragg, J. and Cockell, C. (2015) Geological repositories: scientific priorities and potential high-technology transfer from the space and physics sectors. Mineralogical Magazine, 79, 1651-1664.

Doulgeris, C., Humphreys, P. and Rout, S. (2015) An approach to modelling the impact of ${ }^{14} \mathrm{C}$ release from reactor graphite in a geological disposal facility. Mineralogical Magazine, 79, 1493-1503. 
Felipe-Sotelo, M., Milodowski, A.E. and Evans, N.D.M. (2015) Inhibition of the formation and stability of inorganic colloids in the alkaline disturbed zone of a cementitious repository. Mineralogical Magazine, 79, 1419-1431.

Guido-Garcia, F., Law, G.T.W., Lloyd, J.R., Lythgoe, P. and Morris, K. (2015) Bioreduction of iodate in sediment microcosms. Mineralogical Magazine, 79, 1343-1350.

Hernandez-Selva, T., Engelberg, D.L., Scenini, F., Fox, D. and McClusky, A. (2015) Manufacturing technology for implementing geological disposal: Electroforming of copper canisters. Mineralogical Magazine, 79, $1521-1528$.

Ikonen, A.T.K. (2015) Requirement of the assessment strategy for biosphere in mature safety cases for nuclear waste repositories - Finland case. Mineralogical Magazine, 79, 1607-1612.

Jobmann, M. and Meleshyn, A. (2015) Evaluation of temperature-induced effects on safety-relevant properties of clay host rocks with regard to HLW/SF disposal. Mineralogical Magazine, 79, 1389-1395.

Justinavicius, D. and Poskas, P. (2015) Temperature and tortuosity effect on gas migration in a high level waste disposal tunnel. Mineralogical Magazine, 79, 1317-1325.

Kowe, R., Delay, J., Hammarström, M., Beattie, T. and Palmu, M. (2015) The Implementing Geological Disposal Technology Platform - addressing the needs of new Member States. Mineralogical Magazine, 79, 1591-1597.

Kronberg, M.A.F., Gugala, J. and Haapala, K. (2015) State-of-the-art and proof-of-concept installations for repository concepts based in crystalline rock. Mineralogical Magazine, 79, 1655-1673.

Kuippers, G., Bassil, N.M., Boothman, C., Bryan, N. and Lloyd, J.R. (2015) Microbial degradation of isosaccharinic acid under conditions representative for the far field of radioactive waste disposal facilities. Mineralogical Magazine, 79, 1443-1454.

Lever, D. and Vines, S. (2015) The carbon-14 IPT: an integrated approach to geological disposal of UK wastes containing carbon-14. Mineralogical Magazine, 79, 1641-1650.

Littlewood, J., Shaw, S., Bots, P., Peacock, C.L., Trivedi, D. and Burke, I.T. (2015) Effect of solution composition on the recrystallization of kaolinite to feldspathoids in hyperalkaline conditions: limitations of pertechnetate incorporation by ion competition effects. Mineralogical Magazine, 79, 1379-1388.

Lord, N.S., Ridgwell, A., Thorne, M.C. and Lunt, D.J. (2015) The 'long tail' of anthropogenic $\mathrm{CO}_{2}$; decline in the atmosphere and its consequences for postclosure performance assessments for disposal of radioactive wastes. Mineralogical Magazine, 79, 1613-1623.
Marshall, T.A., Morris, K., Law, G.T.W., Mosselmans, J.F. W., Bots, P., Roberts, H. and Shaw, S. (2015) Uranium fate during crystallization of magnetite from ferrihydrite in conditions relevant to disposal of radioactive waste. Mineralogical Magazine, 79, 1265-1274.

Martell, M. and Van Berendoncks, K. (2015) Integrating societal concerns into research and development (R\&D) on geological disposal at the national level. Mineralogical Magazine, 79, 1563-1571.

Mason, R.M., Martin, J.K., Smith, P.N. and Winsley, R.J. (2015) Consequence modelling of hypothetical postclosure criticality events for spent fuel disposal. Mineralogical Magazine, 79, 1505-1513.

Moyce, E.B.A., Milodowski, A.E., Morris, K. and Shaw, S. (2015) Herbert's Quarry, South Wales - an analogue for host rock alteration at a cementitious radioactive waste repository. Mineralogical Magazine, 79, 1407-1418.

Myers, S., Holton, D. and Hoch, A. (2015) Thermal dimensioning to determine acceptable waste package loading and spatial configurations of heat-generating waste packages. Mineralogical Magazine, 79, 1625-1632.

Payne, L., Heard, P.J. and Scott, T.B. (2015) The use of magnetic sector secondary ion mass spectrometry to investigate ${ }^{14} \mathrm{C}$ distribution in Magnox reactor core graphite. Mineralogical Magazine, 79, 1327-1334.

Poskas, P., Narkuniene, A. and Grigaliuniene, D. (2015) Overview of the Lithuanian program for disposal of RBMK-1500 spent nuclear fuel. Mineralogical Magazine, 79, 1581-1589.

Quirke, J., Henderson, C.M.B., Pattrick, R.A.D., Rosso, K.M., Dent, A., Sharples, J.W. and Pearce, C.I. (2015) Characterizing mineralogy and redox reactivity in potential host rocks for a UK geological disposal facility. Mineralogical Magazine, 79, 1353-1367.

Reid, C., Lunn, R., El Mountassir, G. and Tarantino, A. (2015) A mechanism for bentonite buffer erosion in a fracture with a naturally varying aperture. Mineralogical Magazine, 79, 1485-1494.

Sherriff, N., Issa, R., Morris, K., Livens, F., Heath, S. and Bryan, N. (2015) Reversibility in radionuclide/ bentonite bulk and colloidal ternary systems. Mineralogical Magazine, 79, 1307-1315.

Tietze-Jaensch, H., Van Iseghem, P., Boucher, L., Dodaro, A., Fuks, L., Guisset, J.P., Koivuranta, S., Lierse, C., Neckel, W., Pina, G., Steyer, S., Van Velzen, L. and Vico del Cerro, E. (2015) ENTRAP and its potential interaction with the IGD-TP. Mineralogical Magazine, 79, 1515-1520.

Van Es, E., Hinchliff, J., Felipe-Sotelo, M., Milodowski, A.E., Field, L.P., Evans, N.D.M. and Read, D. (2015) Retention of chlorine-36 by a cementitious backfill. Mineralogical Magazine, 79, 1297-1305.

Walke, R.C., Thorne, M.C., Smith, J.T. and Kowe, R. (2015) Representation of estuarine, coastal and marine 


\section{INTRODUCTION}

biosphere systems within post-closure performance assessments supporting geological disposal of higher activity radioactive wastes in the UK. Mineralogical Magazine, 79, 1467-1474.

Wieland, E. and Hummel, W. (2015) Formation and stability of ${ }^{14} \mathrm{C}$-containing organic compounds in alkaline iron-water systems: Preliminary assessment based on a literature survey and thermodynamic modelling. Mineralogical Magazine, 79, 1275-1286.

Williamson, A.J., Morris, K., Boothman, C., Dardenne, K., Law, G.T.W. and Lloyd, J.R. (2015) Microbially mediated reduction of $\mathrm{Np}(\mathrm{V})$ by a consortium of alkaline tolerant $\mathrm{Fe}(\mathrm{III})$-reducing bacteria. Mineralogical Magazine, 79, 1287-1295.

Winsley, R.J., Baldwin, T.D., Hicks, T.W., Mason, R.M. and Smith, P.N. (2015) Understanding the likelihood and consequences of post-closure criticality in a geological disposal facility. Mineralogical Magazine, 79, 1551-1562.

Wiseall, A.C., Cuss, R.J., Graham, C.C. and Harrington, J.F. (2015) The visualization of flow paths in experimental studies of clay-rich materials. Mineralogical Magazine, 79, 1335-1342.

Xiong, Q. and Jivkov, A.P. (2015) Analysis of pore structure effects on diffusive transport in Opalinus clay via pore network models. Mineralogical Magazine, 79, 1369-1377.

Yang, W., Lunn, R. and Tarantino, A. (2015) MEMS sensor-based monitoring system for engineered geological disposal facilities. Mineralogical Magazine, 79, 1475-1483.

Zihms, S.G. and Harrington, J.F. (2015) Thermal cycling: impact on bentonite permeability. Mineralogical Magazine, 79, 1543-1550. 